\title{
An Operational Metric or An Operational Capability? The Role of Growth in Inventory Efficiency Growth
}

\author{
Andrew S. Manikas \\ Assistant Professor of Operations Management \\ College of Business, University of Louisville, Louisville, KY 40292 \\ E mail: andrew.manikas@louisville.edu (Corresponding Author) \\ Pankaj C. Patel \\ Frank J. and Jane E. Ryan Endowed Chair in Strategy and Innovation \\ Management Department, Villanova University, Villanova, PA 19085 \\ Email : pankaj.patel@villanova.edu
}

\begin{abstract}
Inventory efficiency is used as an operational benchmark in comparing performance against competitors. In this study, we propose extending to inventory efficiency growth over time on performance. Analyzing data from 1,286 US firms from 2003 to 2013 reveals that firms with significant improvements in inventory efficiency over time realize higher performance. Marketing efficiency, operational slack, and negative sales surprise negatively affect inventory efficiency growth. Overall, to realize higher performance, managers must aim to improve inventory efficiency growth over time and manage three levers of marketing efficiency, operational slack, and negative sales surprise.
\end{abstract}

Keywords: inventory efficiency; growth; longitudinal; empirical; manufacturing

\section{INTRODUCTION}

Practices in a wide range of industries show that inventory turnover appears to be anything but static. Consider these examples: After promising sustained efforts to reduce inventories in the third quarter of 2012, Taiwan Semiconductor Manufacturing Co. (TSMC) stock rose by 2.8\% (Culpan, 2013). Saks Fifth Avenue improved performance by consistently improving inventory management during the 2008 recession (Timberlake, 2011). In 2014, Doug Oberhelman, the CEO of Caterpillar, announced that through sustained improvement in inventory turnover, it aims to realize profit growth by $15 \%$ in 2015 (Kaskey, 2014). And, through improved inventory turnover during four quarters in 2012, Walmart aimed to boost US sales by $\$ 5$ billion (Hall, 2012). Even for technology firms such as Apple, the ability to improve inventory turnover over time indicates competitive advantage. Firms are focusing increasingly on improving inventory turnover over time (see Figure 1), with such efforts seeming to be a source of improved performance.

Yet the decision to improve inventory turnover over time could have both positive and negative implications for managers. Increasing inventory turnover over time requires an increased focus on integrating operational resources, which in turn increases vulnerability to external changes (Lawrence and Lorsch, 1967; Modi and Mishra, 2011). Significant inventory turnover growth could result in less flexibility, because operational resources must be coordinated efficiently to improve inventory turnover growth continuously. Such efforts, however, may help develop reliable, trusting, and cooperative supply chain relationships (Lee, 2004). The opening examples call for a dynamic view of inventory turnover, where sustained efforts to improve inventory turnover leads to higher performance. This subsequently leads to inventory turnover growth, or an increase in inventory turnover over time, which could be an operational capability and not merely a hygiene factor (cf. Herzberg, 1974; Morgan et al., 2007). Using inventory turnover growth to indicate cumulating efficacy of operations indicates a firm's ability to coordinate operational activities that continuously improve inventory turnover over time.

Traditionally, operations management inventory turnover has been an important benchmark of lean manufacturing (Huson and Nanda, 1995; Schonberger, 2007) and is considered an important performance criteria in evaluating operational performance (Inman et al., 2011; Rabinovich et al., 2003). With both practitioners and academics calling for theory and practice related to improving inventory performance, the question of whether continuous improvements in inventory turnover lead to improved financial performance remains unexplored. Rajagopalan and Malhotra (2001) found that between 1961 and 1994, inventory ratios improved, but they do not assess the effects of sustained improvements in inventory ratios. Chen et al. (2005) found that among publicly traded US firms, inventories of raw material and work-in-process have declined, but they did not observe change in finished goods inventory during the period 1981 and 2000. In a subsequent study, Chen et al. (2007) found that US retail and wholesale firms had reduced their inventory turnover between 1995 and 2004. Rumyantsev and Netessine (2007) found that inventory management is positively related to earnings, 
whereas others have found support for inventory management on performance in the retail sector (Alan et al., 2014) and the manufacturing sector (Steinker and Hoberg,
2013). Still, whether inventory turnover growth over time leads to higher returns remains an unexplored but important question.

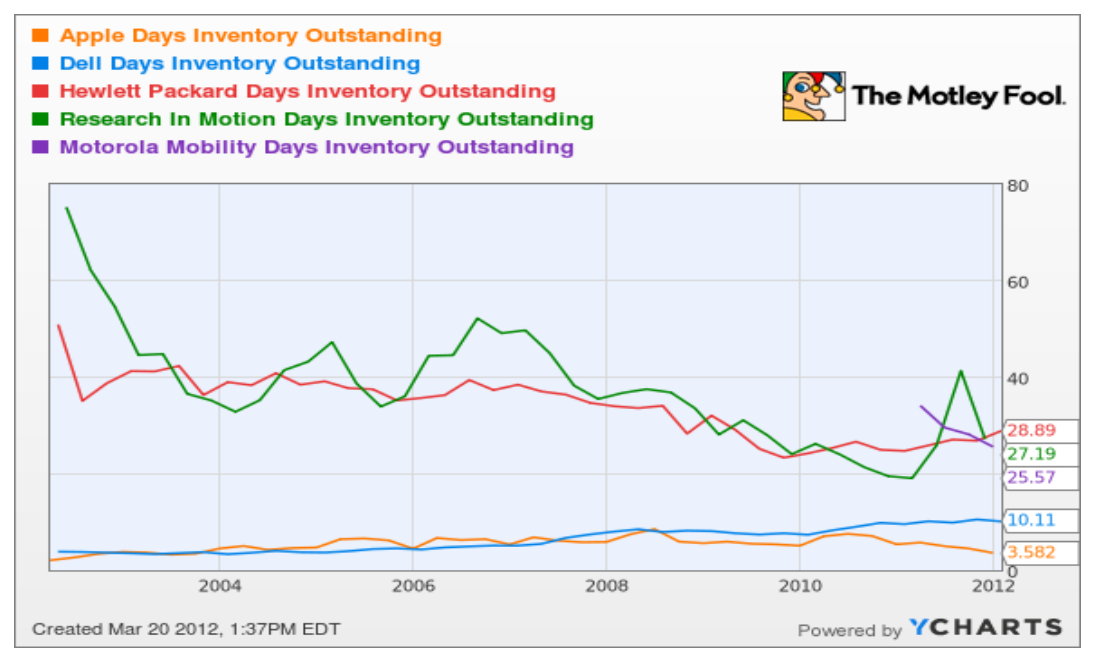

Figure 1 Importance of Reducing Inventory Efficiency Time in Technology Sector Source: (Niu, 2012)

In the present study, we conceptualize and operationalize inventory turnover growth as changes in inventory turnover conditional on time. Akin to linear growth models, the "slope" of inventory turnover over time is the proposed concept of interest. By way of illustration, envision that inventory turnover in a firm is $1.2,1.23,1.18$, 1.24 , and 1.26 during a five-year period. Prior work on inventory turnover in a panel data setting includes these levels of inventory turnover to predict performance during each firm year. In the proposed model, however, we focus on the trend of inventory turnover. The beta of the five aforementioned values of inventory turnover regressed on time (years 1 to 5 ) is 0.013 . In other words, in each year, inventory turnover increases by 0.013 on average. A positive beta indicates that the company has been able to improve its inventory turnover.

We develop a three-pronged conceptual model. First, a firm may have a non-significant beta. In this case, inventory turnover could be a hygiene factor and a potential calibrator for operational activities but does not directly impact performance. We thus explore: Is inventory turnover a hygiene $^{1}$ factor or an operational capability? If there is no difference in performance among firms with no significant growth in inventory turnover over firms with significant growth in inventory turnover, then efforts toward increasing inventory turnover may be less meaningful.

Second, we ask: Do firms with a higher beta of inventory growth realize higher performance than those with a lower beta? This research question helps answer whether sustained efforts toward inventory turnover growth further improve performance, whereas the first research questions asks whether significant inventory turnover growth $(=1$; else $=0$ ) is better than non-significant inventory turnover growth.

Third and finally, if firms with significant inventory turnover growth realize higher performance than those with non-significant inventory turnover growth, and if firms with increasing beta of inventory turnover growth have higher performance than those with lower beta, it is important for operations managers to understand the drivers of inventory turnover growth. Recent work in the retail sector has focused on the effects of gross margin, capital intensity, and sales surprise on inventory turnover (Gaur et al., 2005); here, sales growth and firm size were positively related to inventory turnover. Sales surprise, defined as higher-than-expected sales, is positively related to inventory turnover (Gaur and Seshadri, 2005; Rajagopalan, 2013; Shan and Zhu, 2013). Among retail firms, increasing sales fluctuations lead to higher inventories (Rajagopalan, 2013). To extend this literature, we focus on identifying drivers of growth in inventory turnover. In a review of literature, Basnet and Seuring (2016) found that the majority of supply chain management literature was related to demand variability, which would manifest itself in sales surprise.

Based on prior literature, we identify three antecedents that drive the growth of inventory turnover. First, market resource efficiency, or the degree to which marketing expenditures vary with sales, provides a platform to improve inventory turnover over time (Modi and Mishra, 2011). Lower marketing efficiency induces greater uncertainty in demand and limits operations' ability to improve inventory efficiency over time. Second, operational slack, or the presence of excess capacity and longer cash-to-cash cycles (Hendricks et al., 2009), limits the growth of inventory efficiency as slack reduces internal and external pressure to improve inventory efficiency. The third antecedent is the effect of negative sales surprise, or actual sales being lower than expected demand. Firms with a negative sales surprise are less likely to have efficacious operational routines to improve inventory efficiency. Negative sales surprise increases overall inventory levels and curtails inventory turnover improvements over time. 

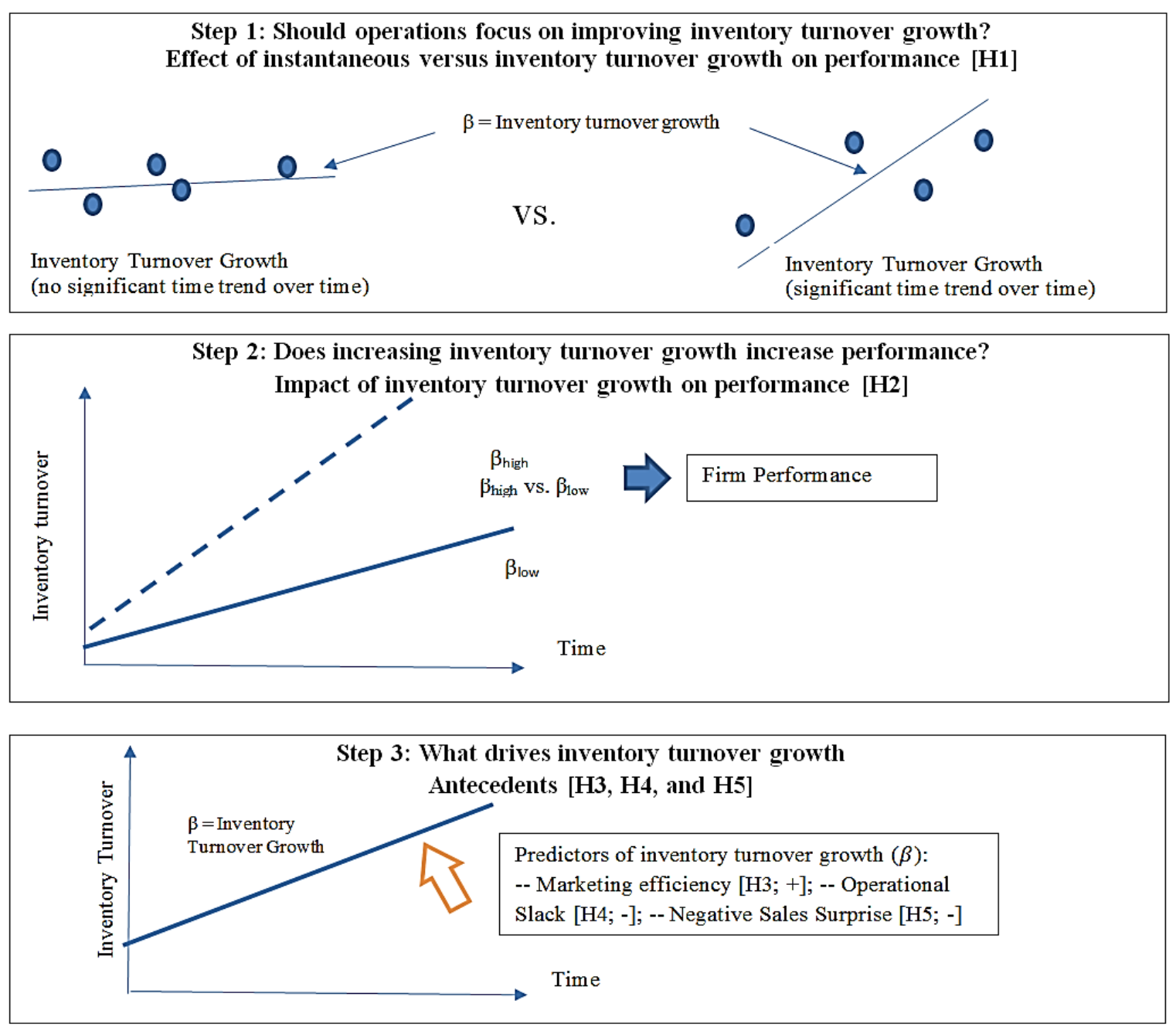

Figure 2 Proposed Model

In summary, we propose three research questions (Figure 2). First, do firms with significant inventory turnover growth realize higher performance than firms with nonsignificant inventory turnover growth? Second, do firms with higher inventory turnover growth over time realize higher performance than those with lower inventory turnover growth? If so, third, what firm characteristics play a vital role in inventory turnover growth?

To measure inventory turnover growth over time, we require at least five consecutive years of information from a firm. This minimum of five years provides stable information on efforts to improve inventory turnover over time and also improves stability of panel data estimates (Wooldridge, 2010). Based on these criteria, we derived a sample of 1,286 manufacturing firms representing 41,067 firm-quarter observations from 2003 to 2013 . To improve the generalizability of our findings, we drew all of our data from manufacturing firms. Works by Rajagopalan and Malhotra (2001) and Chen and colleagues $(2005 ; 2007)$ have drawn on a wide range of industries. Therefore, to continue their work, we draw our sample from manufacturing firms. In the following sections, we develop the hypotheses and describe the sample and analytical approach. To conclude, we discuss the results and implications for managers.

\section{THEORETICAL DEVELOPMENT AND HYPOTHESES}

Inventory turnover - the ratio of sales to inventoryhas been studied extensively in both analytical and empirical literature. Models in the analytical literature include economic order quantity (EOQ) models and the newsvendor problem, among others (Chan et al., 2004; Qin et al., 2011; Urban, 2005). In the empirical literature, based on correlational structures (cross-sectional or panel studies), inventory management has been shown to improve performance (Gaur and Kesavan, 2009; Huson and Nanda, 1995) and is considered an important component of lean manufacturing capabilities (Demeter and Matyusz, 2011). The ability to vary inventory levels with sales has been shown to increase a firm's stock market returns (Steinker and Hoberg, 2013) and to lower the cost of capital (Irvine, 1981). Other studies have found that inventory management improves earnings (Rumyantsev and Netessine, 2007) or stock performance (Aghazadeh, 2009). Modi and Mishra (2011), however, found that inventory turnover had decreasing returns to firm performance. Eroglu and Hofer (2011) cautioned that inventory leanness has an inverted-U type relationship with performance; however, their recent work finds that nonlinear effects of inventory leanness are conditional on environmental conditions (Eroglu and Hofer, 2014). Although this body of work has focused on the effects of inventory in a cross-sectional or panel data setting, 
assessing the effects of inventory turnover over time indicates an important operational capability.

\subsection{Inventory Turnover: Level Versus Slope}

Whether operations should focus on improving inventory turnover over time remains an unexplored issue. On one hand, inventory turnover lowers holding costs, lowers obsolescence, has spillover effects on improving other operational activities, and improves supply chain relationships. Firms improving inventory turnover realize lower inventory costs and the resulting operational spillovers improve forecasting, enhance material flow, and improve delivery reliability. Such firms also are able to improve trust with supply chain partners by demonstrating their ability to improve the flow of goods through inventory turnover growth.

The notion of inventory turnover growth proposed here moves from the traditional correlation structure-based analysis in a cross-sectional or panel setting to a linear growth model- based conceptualization (de Menezes et al., 2010). Kher and Laurenceau (2011) proposed that linear growth models indicate learning-by-doing, whereas improvements in an operational characteristic over time indicate learning. Learning-by-doing is an important component of developing capabilities. Drawing on past experiences and a stock of resources, firms engage in either passive (Jovanovic, 1982) or active learning (Ericson and Pakes, 1995) to hone inventory efforts into sustained operational activities. More specifically, inventory turnover growth requires learning-by-doing (Jovanovic, 1982) using existing operational resources to apply operational skills and knowledge. Such efforts foster experimentation and learning-by-doing to realize consistent improvements in inventory turnover (Politis, 2005).

Whereas inventory turnover growth focuses on the slope of inventory turnover over time, managers may focus on maintaining necessary levels of inventory or a level of acceptable inventory turnover. Furthermore, inventory turnover below hygiene levels could lower performance due to increasing costs and deteriorating supply chain relationships, whereas sustained improvements in inventory turnover growth may also lead to decreasing returns. Sustained inventory turnover growth may stretch operational resources, limit internal flexibility by lowering slack, and lower the firm's ability to respond to shocks.

Traditionally, inventory has been considered a hygiene factor in operations; therefore, the choice between "level" (as a hygiene factor) and "slope" (as an operational capability) of inventory turnover is an important decision criterion. Based on the above discussion on the benefits and costs of focusing on inventory turnover, and based on practitioner evidence as presented in the introduction, we propose that firms with significant improvements in inventory turnover over time realize higher performance than firms with nonsignificant improvements in inventory over time:

Hypothesis 1: Significant growth in inventory turnover over time is positively related to performance than non-significant growth in inventory turnover over time.

\subsection{Inventory Turnover Growth and Performance}

Drawing on an extensive literature regarding the effects of inventory efficiency on firm performance (Lee and Billington, 1992), inventories buffer organizations from environmental changes, and inventory turnover is positively related to firm performance (Bharadwaj et al., 2007; Capkun et al., 2009; Hofer et al., 2012). Inventory turnover growth over time improves performance by lowering holding costs, limiting waste, and improving inventory flow and channel operational resources toward more productive use. The additional resources made available by increasing inventory turnover growth over time could allow the firm to invest in developing operational competencies, improving trust, and fine-tuning coordination and communication with supply chain partners to improve performance. Supply chain partners prefer to collaborate with firms that reliably improve inventory turnover over time because this may allow increased revenues and decreased costs that may be shared across the chain (Fawcett et al.

Inventory turnover growth is realized by continuously improving and learning-by-doing. Inventory efficiency growth improves inventory management routines, lowers mismatch in supply and demand, hones both internal and external operational coordination routines, and improves the firm's ability to adapt to customer needs and market demands. Higher inventory turnover growth lowers variations in manufacturing processes and reduces overall costs. In the long-term, as internal stocks closely match demand, firms can shrink their fixed asset base in logistics to reduce costs overall. As increasing inventory efficiency leads to improved machine utilization, operations managers can more efficaciously engage in capacity planning. Inventory efficiency growth lowers demand censoring (Downs et al., 2001), reduces restocking costs (Evans, 1968), and improves supply chain relationships (Cachon and Fisher, 2000; Lee and Billington, 1992). Overall, therefore, we propose:

\section{Hypothesis 2: Inventory turnover growth is positively related to performance.}

We focus on three theoretically grounded drivers that affect inventory outcomes: (1) marketing efficiency (Modi and Mishra, 2011), (2) operational slack (Hendricks and Singhal, 2005), and (3) negative sales surprise (Gaur et al., 2005). Marketing efficiency improves the allocation of marketing resources in tandem with changing sales. A firm with low marketing efficiency may not efficaciously manage customer relationships or demand. Due to potential demand uncertainty resulting from lower marketing efficiency, operations may not be able to enhance learning-by-doing to improve inventory efficiency over time. Facing lower marketing efficiency, operations managers prefer to hold buffers to meet uncertain demand; therefore, they may not be able to improve inventory turnover over time. Operational slack, or excess capacity and longer cash conversion cycles, reduce the incentive to improve inventory efficiency, because marginal costs from limited capacity utilization could offset marginal gains from improved inventory turnover. Longer cash-to-cash cycle lowers incentives to improve inventory turnover by increasing days in inventory. Finally, firms with limited ability to forecast demand, 
specifically negative sales surprise (sales lower than expected demand), are less able to initiate efforts to improve inventory turnover.

\subsection{Marketing Resource Efficiency and Inventory Turnover Growth}

As introduced above, growth in inventory efficiency is conditional on growth in marketing efficiency. The ability to allocate and manage marketing resources is essential for improving forecasting and managing demand. As a boundary spanner between the firm and the customers, the ability of the marketing function to allocate resources in tandem with sales indicates that the firm is monitoring the pulse of customer demand (Hooley et al., 2005). Uses marketing resources efficiently inculcates necessary routines into the marketing function to allocate resources efficiently to meet customer demand through promotion, sales, and new product development (Dutta et al., 1999). Effective marketing efficiency improves branding and reputation and promotes timely development of products that customers demand. Because marketing efficiency leads to improved sales predictions, it is closely related to improving inventory turnover.

Notably, higher marketing efficiency requires greater coordination with the operations function to meet demand in a timely fashion (Kleindorfer and Saad, 2005). To hold inventory in line with changing sales, inventory managers must receive increasingly accurate demand forecasts from marketing. As marketing efficiency improves reliability in customer demand, it in turn provides a platform for improving inventory turnover. Less dynamic marketing resource efficiency entails greater slack in marketing resources and is a signal of higher variability. This results in an internal "bullwhip," where operations focus on maintaining buffers to meet highly variable demand from marketing. Assured by greater efficiency in marketing, however, rather than fighting fires and maintaining buffers, operations can focus on improving inventory turnover over time. Against this background, we propose:

Hypothesis 3: Marketing efficiency is positively related to inventory turnover growth.

\subsection{Operational Slack and Inventory Turnover Growth}

We posit that higher levels of operational slack inhibit inventory turnover growth. Slack is the difference between existing resources and current demands (Bourgeois, 1981). Operational slack, specifically excess capacity and longer cash-to-cash conversion cycles, provide significant buffers that limit the firm's ability to focus on improving inventory efficiency over time (Hendricks et al., 2009). Prior literature shows that managers prefer the "quiet life" in the presence of slack (Berger and Hannan, 1998) and are therefore less likely to focus on intense activities such as improving inventory efficiency over time. Longer cash-to-cash cycles buffer managers from the pressures of improving inventory efficiency and represent less lean supply chains. This further reduces pressures from supply chain members to improve inventory efficiency over time. Because the firm's technical is increasingly guarded by operational slack from potential demand surges, managers are less willing to engage in greater information processing (Galbraith, 1973) and sustained learning to increase inventory turnover growth. Overall, we posit that higher operational slack lowers inventory turnover growth:

Hypothesis 4: Operational slack in the firm is negatively related to inventory turnover growth.

\subsection{Negative Sales Surprise and Inventory Efficiency Growth}

Gaur et al. (2005) proposed the concept of sales surprise, defined as actual demand in excess of projected demand. Here, we propose sales surprise as an antecedent to inventory performance. Because positive sales surprise (actual demand in excess of projected demand) presents significant shortages, we posit that negative sales surprise (actual demand less than projected demand) leads to lower inventory turnover growth over time. A negative sales surprise, which indicates poorer forecasting ability, limits the firm's ability to improve inventory efficiency over time. Because operational resources are allocated based on projected demand, firms that consistently have a negative sales surprise have excess capacity in warehouses and thus inventory surplus. Greater negative sales surprise over time reduces a firm's ability to improve learning by doing to improve inventory turnover. Because operational capabilities are cumulative, negative sales surprise limits inventory turnover growth:

Hypothesis 5: Negative sales surprise lowers growth in inventory turnover.

\section{DATA AND METHODS}

To test Hypothesis 1, we code firms with significant change in inventory turnover growth as 1 and those with nonsignificant change in inventory turnover growth as 0 . The slope of inventory turnover over time is used to predict performance in Hypothesis 2. Next, the antecedents predict the inventory turnover growth, or slope, to test for Hypotheses 3, 4, and 5.

\subsection{Sampling Strategy}

The present study's research questions focus on what drives improvement in inventory turnover over time and the subsequent effects of such growth on firm performance. We therefore draw on a sample of manufacturing firms with at least 20 firm-quarter observations. Prior studies on inventory management have drawn on samples of retail firms (Gaur et al., 2005; Gaur and Kesavan, 2009; Rajagopalan, 2013). The research questions in those studies focused on the effects of sales surprise, whereas the hypotheses in the present study aim to understand the effects of inventory turnover growth in rolling windows on subsequent performance. Because retail establishments have fixed capacity, and improvements in inventory efficiency are conditional on local economic conditions and geographic competition, we draw on a comprehensive sample of manufacturing establishments. This choice is also in line with recent work on inventory efficiency that has drawn on a sample of manufacturing establishments (Chen et al., 2005; Chen et al., 2007; Steinker and Hoberg, 2013). 


\subsection{Sample Description}

We draw on quarterly data of manufacturing firms listed in the COMPUSTAT database under SIC codes from 20 to 39. To draw stable panel data estimates, we drop firms with fewer than five continuous panels (Wooldridge, 2010). Based on this cutoff, our final sample consists of 1,286 firms representing 41,067 firm-quarter observations from 2003 to 2013. Due to greater fidelity in the electronic data collation in the late 1990s, firm-years from 2003 onward have continuous information for at least five years starting in 2003.

Table 1 provides information on the distribution of firms across different manufacturing sectors. For Hypotheses 1 and 2, return on assets (ROA) is the outcome variable, and for Hypotheses 3, 4, and 5, inventory turnover growth is the outcome variable.

Table 1 Descriptive Statistics

\begin{tabular}{clccc}
\hline SI & Description & $\begin{array}{c}\text { No. } \\
\text { Observations }\end{array}$ & $\begin{array}{c}\text { Return on } \\
\text { Assets }\end{array}$ & $\begin{array}{c}\text { Inventory Turnover } \\
\text { Growth }\end{array}$ \\
\hline 20 & Food \& Kindred Products & 2,130 & -0.0002 & 0.0074 \\
21 & Tobacco Products & 140 & 0.0334 & 0.0242 \\
22 & Textile Mill Products & 395 & -0.0031 & 0.0337 \\
23 & Apparel \& Other Textile Products & 732 & 0.0103 & 0.0128 \\
24 & Lumber \& Wood Products & 456 & -0.0053 & 0.0071 \\
25 & Furniture \& Fixtures & 682 & 0.0061 & 0.0024 \\
26 & Paper \& Allied Products & 728 & 0.0143 \\
27 & Printing \& Publishing & 610 & 0.0068 & 0.0022 \\
28 & Chemical \& Allied Products & 7,159 & 0.0059 & 0.0219 \\
29 & Petroleum \& Coal Products & 187 & 0.0140 \\
30 & Rubber \& Miscellaneous Plastics Products & 887 & 0.0111 & 0.0159 \\
31 & Leather \& Leather Products & 91 & 0.0105 & 0.0107 \\
32 & Stone, Clay, \& Glass Products & 458 & 0.0024 & 0.0070 \\
33 & Primary Metal Industries & 1,512 & 0.0191 & 0.0199 \\
34 & Fabricated Metal Products & 1,247 & 0.0080 & 0.0103 \\
35 & Industrial Machinery \& Equipment & 5,599 & 0.0104 & 0.0114 \\
36 & Electronic \& Other Electric Equipment & 8,284 & 0.0138 & 0.0114 \\
37 & Transportation Equipment & 2,360 & 0.0030 & 0.0142 \\
38 & Instruments \& Related Products & 7,410 & -0.0103 & 0.0142 \\
\hline $20-38$ & All Industries & 41,067 & -0.0030 & 0.0063 \\
\hline
\end{tabular}

Notes: 1,256 firms representing 41,067 firm-quarter observations from 2003-2013

\subsubsection{Dependent Variable: $\mathrm{ROA}$ (H1 and $\mathrm{H} 2$}

Return on assets is a proximal outcome of improving inventory turnover over time and has been used widely as an outcome variable in studies theorizing the effects of inventory turnover on performance (e.g., Eroglu and Hofer, 2011; Modi and Mishra, 2011). Furthermore, stock marketrelated outcomes such as Fama-French returns or Tobin's Q may not include the effects of process-related improvements such as inventory efficiency growth, but include broader firm-related fundamentals. As presented in the robustness checks, we do not find support for the effects of inventory turnover growth on Fama-French returns or Tobin's Q. Return on assets is operationalized as the ratio of net income in the quarter to total assets during the quarter.

\subsubsection{Dependent variable: Inventory turnover growth (H3, H4, and H5)}

Inventory turnover is based on aggregate inventory measured on quarterly basis at the four-digit SIC (Modi and Mishra, 2011):

$I E_{i t}=\frac{\left(\frac{\text { Sales }_{i t}}{\text { Inventor }_{i t}}\right)-\mu\left(\frac{\text { Sales }_{t}}{\text { Inventory }_{t}}\right)}{\sigma\left(\frac{\text { Sales }_{t}}{\text { Inventory }_{t}}\right)}$
Inventory resource efficiency is calculated for firm $i$ for quarter $t$, Sales $i t$ is the sales of firm $i$ in quarter $t$, and Inventory $_{i t}$ is the inventory of firm $i$ in quarter $t$.

We calculate inventory turnover growth by regressing inventory efficiency in the past eight quarters lagged to the current quarter over the past eight quarters. The beta of the regression is the measure of inventory efficiency growth, with a higher positive beta indicating inventory efficiency growth. Although five-year rolling windows would be more stable, such longer time spans are also subject to unobserved heterogeneity effects. Growth in inventory over eight quarters provides better estimates than a four-quarter window, which could be influenced by seasonal effects. Windows longer than two years could confound the effect of inventory turnover improvements on performance.

To test for Hypothesis 1, we identified significant $(=1)$ and non-significant beta $(=0)$. We then use this as a predictor variable to assess the effects of significant change in inventory turnover growth relative to non-significant change in inventory turnover on performance. To test Hypotheses 2, 3,4 , and 5 , we use the continuous measure of beta, as an indicator of inventory turnover growth.

\subsection{Predictor Variables for Inventory Turnover Growth}

3.3.1. Marketing Efficiency 
The measure of marketing efficiency is drawn from Modi and Mishra (2011), who use marketing resource efficiency to predict firm performance in a panel data setting:

Marketing efficiency $y_{i t}=\frac{\left(\frac{\text { sales }_{i t}}{\text { SG\&A }_{i t}}\right)-\mu\left(\frac{\text { Sales }_{t}}{\text { SG\&A }_{t}}\right)}{\sigma\left(\frac{\text { Sales }_{t}}{\text { SG\&A }_{t}}\right)}$

Where $S G \& A=$ selling and general administrative expenses in quarter $t ; \mu$ is the mean, and $\sigma$ is the standard deviation based on all firms in the four-digit SIC code during quarter $t$. Because ratio is a standardized measure, its value ranges from -3 to +3 with a mean of zero. Higher values indicate higher marketing efficiency. A positive coefficient indicates that growth in marketing efficiency increases inventory efficiency.

\subsubsection{Operational Slack}

The measure of operational slack growth is based on Hendricks et al. (2009). Based on their framework, we rely on two indicators: (1) excess capacity (the ratio of annual sales to net property, plant, and equipment) and (2) cash-tocash cycle (days in inventory plus days in accounts receivable minus days in accounts payable. Each quarterly item of cash-to-cash cycle is measured as follows:

Days in inventory $y_{i t}=91.25 \times \frac{\text { average inventory }_{i t}}{\text { Cost of goods } \text { sold }_{i t}}$

Days of accounts receivables $_{i t}=91.25 \times$

$\frac{\text { average accounts receivable }_{i t}}{\text { Sales }_{\text {it }}}$

Days of accounts payable it $=91.25 \times$ $\underline{\text { average accounts payable }}$ it

Cost of goods sold $i t$

For a yearly measure of the above measures, 365 days are used; therefore, to use quarterly data we divide 365 by 4 and use 91.25 days in a quarter to operationalize the above measures. Higher values of both indicators express greater operational slack. We take the average of standardized values of two indicators in each quarter as a measure of operational slack. We do not include the third indicator from Hendricks et al. (2009) — days in inventory-because it is a proxy for the dependent variable (inventory efficiency) for Hypotheses 1, 2, and 3. A negative coefficient would indicate that operational slack lowers inventory efficiency growth.

\subsubsection{Negative Sales Surprise}

We also aim to assess the extent to which a firm improves in lowering negative sales surprise over time. We draw on prior literature to measure negative sales surprise (Gaur et al. [2005] and used in Kolias et al. [2011], Shan and Zhu [2013], and Rajagopalan [2013]). Continuing from Gaur and colleagues (2005) using linear exponential smoothing method proposed by Holt (2004), sales forecast for firm $i$ during quarter $t$ is specified as:

$$
\text { Sales Forecast } \text { it }_{i, t-1}+T_{i, t-1}
$$

where $L_{i, t-1}$ and $T_{i, t-1}$ are linear exponential smoothed series specified as:

$$
\begin{gathered}
L_{i t}=\alpha S_{i t}+(1-\alpha)\left(L_{i}+T_{i, t-1}\right) \\
T_{i t}=\gamma\left(L_{i t}-L_{i, t-1}\right)+(1-\gamma) T_{t, t-1}
\end{gathered}
$$

where $S_{i t}=$ the total sales for firm $i$ in quarter $t ; \alpha$ and $\gamma$ represent weighting constants from 0 to 1 . Based on Gaur and colleagues (2005), we use the value of 0.75 for both $\alpha$ and $\gamma$.

Negative sales surprise is calculated as

Negative sales surprise $=1-\frac{\text { Sales }_{i t}-\text { Sales Forecast }_{i t}}{\text { Sales }_{i t}}$,

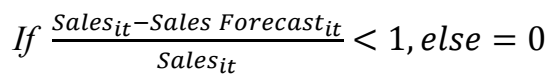

A positive coefficient would indicate that negative sales surprise is positively related to inventory efficiency growth.

\subsection{Control Variables}

We control for firm size (natural log of assets), firm age (years since establishment), natural log of earnings, and production efficiency. Larger firms suffer from learning traps (Ahuja and Morris Lampert, 2001) and are required to make significant changes within and outside the firm to improve inventory turnover growth. Smaller firms, therefore, may have a distinct advantage increasing inventory efficiency growth. Due to their larger asset base, larger firms are also expected to have a lower return on assets. Younger firms are able to adapt rapidly, and due to their smaller size, they are able to engage in rapid learning.

Because we cannot fully observe firm-related operational characteristics, to control for myriad factors affecting performance, we control for past earnings measured as natural log of net income.

We control for production efficiency based on Modi and Mishra (2011):

$$
\text { Production efficiency }_{i t}=\frac{\left(\frac{\text { Sales }_{i t}}{P P E_{i t}}\right)-\mu\left(\frac{\text { Sales }_{t}}{P P E_{t}}\right)}{\sigma\left(\frac{\text { Sales }_{t}}{P P E_{t}}\right)}
$$

where PPE is property, plant, and equipment in for firm $i$ in quarter $t$.

Inventory turnover, market efficiency, and production efficiency are adjusted for industry-level factors; therefore, industry-level dummies are not included due to potential multicollinearity from including both industry dummies and industry-adjusted variables.

\subsection{Results}

As listed in Table 1, SIC 21 (Tobacco products) had the highest ROA of $3.34 \%$, and SIC 28 (Instruments and Related Products) had the lowest ROA of $-2.45 \%$. Lowest inventory efficiency growth of 0.0022 was in SIC 27 (Printing and Publishing); the highest inventory efficiency of 0.0337 was in SIC 22 (Textile Mill Products). Table 2 lists the mean, standard deviation, and correlations. 
Table 2 Correlation and Descriptive Statistics

\begin{tabular}{|c|c|c|c|c|c|c|c|c|c|c|c|}
\hline & Mean & $\begin{array}{l}\text { Std } \\
\text { Dev }\end{array}$ & $\begin{array}{l}\text { Return } \\
\text { on } \\
\text { Assets }\end{array}$ & $\begin{array}{l}\text { Firm } \\
\text { Size }\end{array}$ & $\begin{array}{l}\text { Firm } \\
\text { Age }\end{array}$ & $\begin{array}{l}\text { Ln } \\
\text { Earnings }\end{array}$ & $\begin{array}{l}\text { Production } \\
\text { Efficiency }\end{array}$ & $\begin{array}{l}\text { Marketing } \\
\text { Efficiency }\end{array}$ & $\begin{array}{l}\text { Operational } \\
\text { Slack }\end{array}$ & $\begin{array}{l}\text { Negative } \\
\text { Sales } \\
\text { Surprise } \\
\end{array}$ & $\begin{array}{l}\text { Inventory } \\
\text { Turnover } \\
\text { Growth }\end{array}$ \\
\hline $\begin{array}{l}\text { Return on } \\
\text { Assets }\end{array}$ & $\overline{0} \overline{0} 0069$ & 0.1457 & 1 & & & & & & & & \\
\hline Firm Size & 2.7278 & 7.7005 & $-0.0330^{*}$ & 1 & & & & & & & \\
\hline Firm Age & $\begin{array}{l}32.906 \\
4\end{array}$ & 5.0744 & $-0.0494^{*}$ & $0.0435^{*}$ & 1 & & & & & & \\
\hline Ln Earnings & 2.1524 & 2.2818 & $0.1045^{\star}$ & $0.5556^{*}$ & $0.1190^{*}$ & 1 & & & & & \\
\hline $\begin{array}{l}\text { Production } \\
\text { Efficiency }\end{array}$ & 0.0000 & 0.9998 & $-0.0224^{\star}$ & $0.3079^{*}$ & 0.0185 & $0.2310^{*}$ & 1 & & & & \\
\hline $\begin{array}{l}\text { Marketing } \\
\text { Efficiency }\end{array}$ & 0.0000 & 0.9998 & 0.0017 & 0.0017 & $\overline{0} .0224^{*}$ & 0.0152 & $0.0463^{*}$ & 1 & & & \\
\hline $\begin{array}{l}\text { Operational } \\
\text { Slack } \\
\text { Negative }\end{array}$ & $\overline{0} .0002$ & 0.6939 & $-0.0266^{\star}$ & $0.0364^{*}$ & $0.0199^{\star}$ & -0.0038 & $-0.0234^{*}$ & $-0.0475^{\star}$ & 1 & & \\
\hline $\begin{array}{l}\text { Sales } \\
\text { Surprise } \\
\text { Inventory }\end{array}$ & 0.0460 & 0.0728 & $0.0284^{*}$ & $\overline{0} .0643^{*}$ & $\overline{0}-1345^{\star}$ & $-0.1277^{*}$ & $-0.0255^{\star}$ & -0.0051 & $0.0379^{*}$ & 1 & \\
\hline $\begin{array}{l}\text { Turnover } \\
\text { Growth }\end{array}$ & $\overline{0} .0037$ & 0.1184 & 0.0165 & $0.0213^{*}$ & $0.0568^{*}$ & $0.0268^{*}$ & 0.012 & $-0.0385^{\star}$ & 0.0119 & $-0.0602^{*}$ & 1 \\
\hline
\end{tabular}

Notes: Listwise deletion based on variables in Model 2 of Table 3

* Significant at $p<0.05$

The Haussmann test was rejected $(p=0.000)$ for all specifications; therefore, we use fixed estimates. Hypothesis 1 proposed that firms with significant inventory turnover growth have higher performance than firms with non- significant turnover growth (Table 3, Model 2: $\beta=0.0085$, $p<0.01$ ). Table 3 presents the effect of significant and nonsignificant inventory turnover growth on ROA (H1).

Table 3 Instantaneous Versus Significant Growth in Inventory Efficiency and Return On Assets [H1]

\begin{tabular}{|c|c|c|}
\hline 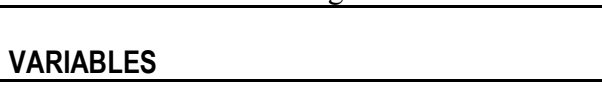 & $\begin{array}{c}(1) \\
\text { ROA } \\
\end{array}$ & $\begin{array}{r}(2) \\
\text { ROA }\end{array}$ \\
\hline Significant inventory turnover growth $(=1)[\mathrm{H} 1]$ & & $\begin{array}{c}0.00848^{\star * *} \\
(0.00214)\end{array}$ \\
\hline Firm Size & $\begin{array}{c}-0.00172^{* * *} \\
(0.000194)\end{array}$ & $\begin{array}{l}-0.00155^{* * *} \\
(0.000201)\end{array}$ \\
\hline Firm Age & $\begin{array}{l}-1.68 \mathrm{e}-05 \\
(0.000306)\end{array}$ & $\begin{array}{l}-1.68 \mathrm{e}-05 \\
(0.000306)\end{array}$ \\
\hline Ln Earnings & $\begin{array}{l}0.0163^{\star * *} \\
(0.000336)\end{array}$ & $\begin{array}{l}0.0157^{* * *} \\
(0.000337)\end{array}$ \\
\hline Production Efficiency & $\begin{array}{l}-0.000340 \\
(0.000448)\end{array}$ & $\begin{array}{l}-0.000336 \\
(0.000448)\end{array}$ \\
\hline Market Efficiency & $\begin{array}{c}0.000426 \\
(0.000472)\end{array}$ & $\begin{array}{c}0.000455 \\
(0.000456)\end{array}$ \\
\hline Operational Slack & $\begin{array}{c}-0.00255^{\star} \\
(0.00135)\end{array}$ & $\begin{array}{c}-0.00870^{* * *} \\
(0.00208)\end{array}$ \\
\hline Negative Sales Surprise & $\begin{array}{c}0.00887 \\
(0.00680)\end{array}$ & $\begin{array}{c}0.00662 \\
(0.00713)\end{array}$ \\
\hline Constant & $\begin{array}{c}-0.00453 \\
(0.0103)\end{array}$ & $\begin{array}{c}-0.00457^{* * *} \\
(0.00101)\end{array}$ \\
\hline Observations & 11,947 & 10,767 \\
\hline R-squared & 0.183 & 0.190 \\
\hline Number of Firms & 1,207 & 1,196 \\
\hline
\end{tabular}


Table 4 Inventory Efficiency Over Firm-Time and Return On Assets [H2]

\begin{tabular}{|c|c|c|}
\hline VARIABLES & $\begin{array}{c}\text { (1) } \\
\text { ROA }\end{array}$ & $\begin{array}{c}\text { (2) } \\
\text { ROA }\end{array}$ \\
\hline Inventory Turnover Growth [H2] & & $\begin{array}{l}0.0135^{\star \star *} \\
(0.00308)\end{array}$ \\
\hline Negative Sales Surprise & $\begin{array}{c}0.00887 \\
(0.00680)\end{array}$ & $\begin{array}{c}0.00933 \\
(0.00713)\end{array}$ \\
\hline Firm Size & $\begin{array}{c}-0.00172^{\star * *} \\
(0.000194)\end{array}$ & $\begin{array}{c}-0.00155^{\star * *} \\
(0.000201)\end{array}$ \\
\hline Firm Age & $\begin{array}{l}-1.68 \mathrm{e}-05 \\
(0.000306)\end{array}$ & $\begin{array}{l}-1.68 \mathrm{e}-05 \\
(0.000306)\end{array}$ \\
\hline Ln Earnings & $\begin{array}{c}0.0163^{* * *} \\
(0.000336)\end{array}$ & $\begin{array}{c}0.0157^{* * *} \\
(0.000337)\end{array}$ \\
\hline Production Efficiency & $\begin{array}{l}-0.000340 \\
(0.000448)\end{array}$ & $\begin{array}{l}-0.000340 \\
(0.000448)\end{array}$ \\
\hline Marketing Efficiency & $\begin{array}{c}0.000426 \\
(0.000472)\end{array}$ & $\begin{array}{c}0.000487 \\
(0.000456)\end{array}$ \\
\hline Operational Slack & $\begin{array}{l}-0.00255^{\star} \\
(0.00135)\end{array}$ & $\begin{array}{c}-0.00880^{* * *} \\
(0.00208)\end{array}$ \\
\hline Constant & $\begin{array}{c}-0.00453 \\
(0.0103)\end{array}$ & $\begin{array}{c}-0.00436^{\star * *} \\
(0.00101)\end{array}$ \\
\hline Observations & 11,947 & 10,767 \\
\hline R-squared & 0.183 & 0.190 \\
\hline Number of Firms & 1,207 & 1,196 \\
\hline
\end{tabular}

Notes. Standard errors in parentheses

$* * * p<0.01, * * p<0.05, * p<0.1$

Table 5 Fixed Effect Estimates (H3, H4, And H5)

\begin{tabular}{|c|c|c|c|c|c|c|}
\hline VARIABLES & $\begin{array}{c}\text { (1) } \\
\text { Inventory } \\
\text { Turnover Growth }\end{array}$ & $\begin{array}{c}\text { (2) } \\
\text { Inventory } \\
\text { Turnover Growth }\end{array}$ & $\begin{array}{c}\text { (3) } \\
\text { Inventory } \\
\text { Turnover Growth }\end{array}$ & $\begin{array}{c}\text { (4) } \\
\text { Inventory } \\
\text { Turnover Growth }\end{array}$ & $\begin{array}{c}\text { (5) } \\
\text { Inventory } \\
\text { Turnover } \\
\text { Growth }\end{array}$ & $\begin{array}{c}\text { (6) } \\
\text { Inventory } \\
\text { Turnover } \\
\text { Growth }\end{array}$ \\
\hline Firm Size & & $\begin{array}{l}-0.00113^{* *} \\
(0.000454)\end{array}$ & $\begin{array}{l}-0.00116^{* *} \\
(0.000454)\end{array}$ & $\begin{array}{l}-0.00110^{* *} \\
(0.000455)\end{array}$ & $\begin{array}{l}-0.000898 \\
(0.000666)\end{array}$ & $\begin{array}{l}-0.000905 \\
(0.000666)\end{array}$ \\
\hline Firm Age & & $\begin{array}{l}0.00452 \\
(0.0513)\end{array}$ & $\begin{array}{l}0.00456 \\
(0.0512)\end{array}$ & $\begin{array}{c}0.000282 \\
(0.0513)\end{array}$ & $\begin{array}{c}0.000282 \\
(0.0513)\end{array}$ & $\begin{array}{c}0.000282 \\
(0.0513)\end{array}$ \\
\hline Ln Earnings & & $\begin{array}{c}-0.00387^{* * *} \\
(0.000770)\end{array}$ & $\begin{array}{c}-0.00374^{* * *} \\
(0.000770)\end{array}$ & $\begin{array}{c}-0.00405^{* * *} \\
(0.000773)\end{array}$ & $\begin{array}{c}-0.00202^{*} \\
(0.00112)\end{array}$ & $\begin{array}{c}-0.00204^{*} \\
(0.00112)\end{array}$ \\
\hline Production Efficiency & & $\begin{array}{l}-0.000784 \\
(0.000988)\end{array}$ & $\begin{array}{r}-0.000782 \\
(0.000988)\end{array}$ & $\begin{array}{l}-0.000752 \\
(0.000989)\end{array}$ & $\begin{array}{c}-0.000241 \\
(0.00149)\end{array}$ & $\begin{array}{c}-0.000255 \\
(0.00149)\end{array}$ \\
\hline Marketing Efficiency [H3] & & & $\begin{array}{c}-0.00553^{* * *} \\
(0.00111)\end{array}$ & & & $\begin{array}{c}-0.00334^{* *} \\
(0.00151)\end{array}$ \\
\hline Operational Slack [H4] & & & & $\begin{array}{c}-0.0134^{* * *} \\
(0.00473)\end{array}$ & & $\begin{array}{r}-0.00201 \\
(0.00692)\end{array}$ \\
\hline Negative Sales Surprise [H5] & & & & & $\begin{array}{c}-0.110^{* * *} \\
(0.0235)\end{array}$ & $\begin{array}{c}-0.110^{* * *} \\
(0.0237)\end{array}$ \\
\hline Constant & $\begin{array}{c}-0.00366^{* * *} \\
(0.000622)\end{array}$ & $\begin{array}{l}-0.146 \\
(1.721)\end{array}$ & $\begin{array}{l}-0.147 \\
(1.720)\end{array}$ & $\begin{array}{c}-0.00267 \\
(1.723)\end{array}$ & $\begin{array}{l}-0.00342 \\
(0.00333)\end{array}$ & $\begin{array}{l}-0.00306 \\
(0.00335)\end{array}$ \\
\hline Observations & 33,351 & 22,785 & 22,785 & 22,753 & 10,779 & 10,767 \\
\hline R-squared & 0.000 & 0.002 & 0.003 & 0.002 & 0.003 & 0.003 \\
\hline Number of Firms & 1,286 & 1,237 & 1,237 & 1,237 & 1,196 & 1,196 \\
\hline
\end{tabular}

Notes. Standard errors in parentheses

$* * * p<0.01, * * p<0.05, * p<0.1$

Table 4 presents the effects of inventory efficiency growth on ROA. Supporting Hypothesis 2, inventory efficiency growth is positively related ROA (Table 4, Model 2: $\beta=0.0135, p<0.01)$. A $1 \%$ increase in inventory efficiency in each of eight quarters leads to $1.35 \%$ increase in ROA.

Table 5 presents the effects of market efficiency, operational slack, and negative sales surprise on inventory efficiency growth. As proposed in Hypothesis 3, market efficiency has a positive effect on inventory efficiency growth (Table 5, Model 3: $\beta=-0.00553, p<0.01$ ). Although the effect is significant, the direction of the effect is opposite of the predicted direction. For one standard deviation increase in market efficiency, there is a $0.55 \%$ decline in inventory efficiency growth. As predicted in Hypothesis 4, operational slack lowers inventory efficiency growth (Table 
4, Model 5: $\beta=-0.0134, p<0.01$ ). In other words, one standard deviation increase in operational slack results in $1.34 \%$ decrease in inventory efficiency growth. Hypothesis 5 predicted that negative sales surprise leads to a decline in inventory efficiency growth (Table 5, Model 5: $\beta=-0.110$, $p<0.01)$. Here, one standard deviation increase in negative sales surprise leads to $11 \%$ decrease in inventory efficiency growth. In the full model, the direction of the effects and significance remain consistent with the stepwise model.

\subsubsection{Practical relevance}

A firm may benefit its financial performance by improving its inventory turnover rate over time. A $1 \%$ increase in inventory turnover growth increases ROA by $1.35 \%$. Cycling through inventory ever more quickly benefits the bottom line. We show here that focusing on increasing turns over time leads to improved return on assets. The estimates for $\mathrm{H} 3$, show that one standard deviation increase in marketing efficiency lowers inventory turnover growth by $0.55 \%$ each year. Similarly, one standard deviation increase in operational slack lowers inventory turnover growth by $-1.34 \%$ each year (H4), and a $1 \%$ increase in negative sales surprise lowers inventory growth rate by $11 \%$ per year (H5). Overall, inventory turnover growth significantly impacts ROA. Operations managers must be cognizant of the effects of operational characteristics such as operational slack and negative sales surprise and effects of market efficiency on inventory turnover growth.

\subsection{Robustness checks}

3.6.1 Alternate Outcome Measures: Fama-French Returns, Tobin's Q, And Gross Margin

We test H1 using three alternate firm performance measures. Fama-French 3-factor market returns $(\beta=-$ $0.0107, p>0.10)$ and Tobin's $\mathrm{Q}(\beta=0.104, p>0.10)$ were not significantly related to inventory turnover growth. Because Fama-French 3-factor returns and Tobin's Q are driven by firm growth prospects and broader firm characteristics, the effects of inventory turnover growth on these market-based outcomes are not supported.

Inventory turnover growth, as an exploitative effort focused on incremental gains, may not be related to stock market-related firm performance measures. Consistent with this argument, we find that inventory efficiency growth is also positively related to gross margin $(\beta=0.011, p<0.10)$.

\subsubsection{Nonlinear Effects}

We further assessed whether squared terms of market efficiency $(\beta=0.00127, p<0.01)$, operational slack $(\beta=-$ $0.00642, p>0.10)$, or negative sales surprise $(\beta=0.0628, p>$ $0.10)$ were related to inventory turnover growth. Among the three predictors, the nonlinear effect of market efficiency had a U-shaped effect on inventory efficiency growth, indicating that both high and low levels of market efficiency growth leads to higher inventory efficiency growth. The nonlinear effects of operational slack and negative sales surprise, however, were not significant.

\section{DISCUSSION}

As noted in the introduction, a variety of firms in different industries aiming to improve their inventory benchmarks over time received a higher stock market valuation. Although operations managers could consider inventory turnover a hygiene factor, the results show that improving inventory turnover leads to an increase in firm value. Sustained year-to-year improvement in inventory turnover clearly has strong implications for managers. The results show that higher marketing efficiency and operational slack stifle inventory turnover growth; indeed, operational slack beneficial in absorbing shocks could deter long-term inventory turnover improvements. Finally, because demand forecasting accuracy has cascading effects on operational activities, the ability to lower negative sales surprise is conducive to improving inventory turnover growth. The results suggest that operational resources and capabilities must be leveraged to improve inventory turnover over time, and maintaining a certain level of inventory turnover may not improve performance (H1). Firms with higher inventory growth further realize higher performance (H2). To extend recent studies focusing on inventory trends in the past decades (Chen et al., 2005; Chen et al., 2007) and produce generalizable results, we drew on a longitudinal sample. We found that marketing efficiency lowered inventory turnover growth, as did operational slack (Hendricks and Singhal, 2005) and negative sales surprise (Gaur et al., 2005).

Work in recent years has called increasingly for a greater focus on reducing inventory (Chen et al., 2005; Cooper and Maskell, 2008; Eroglu and Hofer, 2014; Hall, 1983), although others have shown that holding excess inventory is essential to buffer the firm against demand fluctuations (Lee et al., 2004). Evidence of declining inventory levels in recent decades indicates that while firms have reduced average inventory holdings, sustained improvements in inventory turnover improves firm performance. An important finding related to the present study's Hypothesis 2 is that inventory turnover growth is positively related to ROA and gross margin. The impact of inventory turnover growth on accounting performance is salient. However, we do not find significant effects for the effect of inventory turnover growth on stock market related outcomes such as Fama-French 3-factor returns or Tobin's Q. Because stock market returns are based on long-term growth prospects, the stock market may not be sensitive to short-term incremental impacts on performance through improved inventory turnover. The effect of inventory management on financial performance outcome indicates not only its tactical advantages but also the strategic advantages of inventory management practices. Because inventory turnover growth is an indicator of improving lean manufacturing practices over time, future research could focus on the effects of growth of lean management practices on performance.

Inventory turnover growth contributes to the operations management literature on learning-by-doing (Abernathy and Townsend, 1975; Hines et al., 2004). Increased accuracy in demand forecasting allows for improved materials planning and scheduling. Furthermore, as the operations department decreasingly plays catch up to meet uncertain demand, it can focus on improving inventory management. Because process improvements require system stability, learning-by-doing to improve inventory turnover is more feasible when firms have lower marketing resource efficiency, have limited operational slack, and have fewer negative sales surprises.

The present study's findings also contribute to the swift-even-flow theory (Schmenner, 2001). Inventory 
turnover growth indicates increasing the swift-even-flow of materials in operations as firms match inventory with sales. Swifter, more even, and improved material flow is realized at lower levels of marketing turnover, operational slack, and negative surprise. Future research could consider focusing on the role of the antecedents in the proposed model in the context of the swift-even-flow model.

\subsection{Practical Implications}

The present study's findings provide managerial guidance on the drivers of improving inventory turnover. Rather than using inventory turnover as a hygiene factor, sustained efforts toward improving inventory turnover improves firm performance. Rather than leveraging inventory turnover as a means to manage operations, inventory turnover growth is necessary to improve performance. Although lean practices have been explored extensively, the process of time-dependent changes in an indicator of lean practices - inventory turnover-is seldom explored. Managers or firms must ensure lower marketing efficiency, lower operational slack, and fewer negative sales surprise situations to improve inventory turnover over time. Coordination between the marketing and operations functions is essential to ensure that market efficiency is not pursued aggressively at the expense of lower inventory turnover growth. Although operations managers are not directly responsible for improving marketing efficiency, lowering operational slack is within their control. Increasing capacity utilization and shortening cash-to-cash cycles could improve inventory turnover in the long-term. Furthermore, investing in systems and procedures to lower negative sales surprise could also be beneficial. The present study's findings also encourage managers to adopt a sustained focus on improving inventory turnover. While improving inventory turnover could be an operational imperative, it has positive effects on overall firm performance.

\subsection{Limitations and Directions for Future Research}

As with all studies, the present study's findings should be interpreted in light of their limitations. First, although we draw on archival and publicly available data from a wide range of manufacturing industries, the findings cannot be generalized beyond publicly traded US manufacturing firms. While past work on inventory trends has focused on a wide range of manufacturing industries (Chen et al., 2005), work on the antecedents of industry outcomes has drawn on the retail (Rajagopalan, 2013) and automobile sectors (Cachon and Olivares, 2010). In relation to these studies, the present study does not draw on detailed weekly or monthly inventory data. In line with Chen and colleagues $(2005,2007)$, we focus on generalizability over reliability. Future studies, however, could focus on fine-grained inventory data from a wide range of manufacturing industries. Second, the findings are not generalizable to smaller or younger manufacturing firms that are not publicly traded, nor do we focus on a specific industry such as perishable food products as done in Fauza et al. (2015).

Third, we focus on aggregate inventory levels, but encourage future studies to examine micro-dynamics related to raw material, work-in-progress, or finished-goods inventories. Fourth, we call on future studies to draw on behavioral operations management to understand how managers improve operational efficiency through the lens of learning-by-doing. Such efforts could require process data from managers and analyses of such information using visual mapping strategy and recursive learning template frameworks (Langley, 1999).

Fifth, we do not explore the dynamics of inventory turnover across industries. In retail industries and other sectors, inventory turnover is a key metric. Among manufacturing firms such as steel or mining, however, inventory turnover is a critical performance factor. Although we adjust the inventory turnover measure for industry effects, different industries have different inventory turnover dynamics. We call on future research to include supply chain dynamics in impacting inventory turnover growth. In addition to internal lean practices, supply chain partners could imbibe necessary routines and coordinate inventory turnover across the supply chain to improve overall inventory dynamics. Future studies could also consider the effect of partners' operational capabilities on transmitting inventory management capabilities.

\section{CONCLUSION}

Traditionally, work on inventory management has focused on instantaneous inventory turnover. Elsewhere, the practitioner literature has emphasized the need to improve inventory over time. Here, the proposed model of longitudinal changes in inventory turnover over time is important for several reasons. First, instantaneous inventory turnover is an operational benchmark that operations departments strive to achieve during a given period. The current framework proposes inventory turnover growth as an operational capability. Although operational capabilities in general result from a diverse range of cumulative capabilities, the proposed framework demonstrates the relevance of improving inventory turnover.

Second, although prior work has increasingly called for coordination between marketing and operations to improve instantaneous inventory turnover, we find that coordinating marketing efficiency and inventory turnover growth may not be possible. The results show that when the marketing department is focused on improving its own efficiency, operations cannot improve inventory turnover. This implies that firms must not encourage all functional areas to pursue efficiency, but instead prioritize the pursuit of efficiency among departments.

Third, although prior work has focused increasingly on the relevance of operational slack in absorbing disruptions, the presence of operational slack negatively affects the pursuit of inventory turnover growth. Without exploring inventory turnover growth, the potential negative effect of operational slack may not have been identified. Operations managers must judiciously maintain adequate operational slack to ensure they pursue operational improvements. Fourth, demonstrating the interconnectedness among operational activities, ameliorating negative sales surprise over time is important for bringing concordance in operational activities and sharpening the firm's focus on improving operational metrics over time. Operations managers that constantly fight fires under negative sales surprise may not improve inventory management efforts. Overall, moving from the traditional focus on instantaneous 
inventory turnover, exploring inventory turnover growth has demonstrated the value of improving inventory turnover and, more importantly, its tradeoffs with marketing efficiency or operational slack.

Although inventory turnover is espoused as a key operational metric extending past research, we propose examining the concept of inventory turnover growth or improvement in inventory turnover over time. We find that market efficiency, operational slack, and negative sales surprise lower inventory turnover growth. One standard deviation increase in market efficiency leads to $-0.55 \%$ decline in inventory turnover growth; similarly, one standard deviation increase in operational slack leads to $-1.34 \%$ decline in inventory turnover growth. The effects of negative sales surprise are relatively higher, where $1 \%$ increases in negative sales surprise leads to $-11 \%$ declines in inventory turnover growth. Negative sales surprise is therefore a key driver of decline in inventory turnover growth. Inventory turnover growth leads to higher performance: a $1 \%$ increase in year-to-year inventory turnover growth increases ROA by $1.35 \%$ and gross margin by $1.1 \%$. Inventory turnover growth is therefore an important operational metric for both researchers and operations managers.

\section{REFERENCES}

Abernathy, W.J., and Townsend, P.L. (1975). Technology, productivity and process change. Technological Forecasting and Social Change 7, pp. 379-396.

Aghazadeh, S.-M. (2009). The impact of inventory turnover ratio on companies' stock performance in the retail industry. International Journal of Services, Economics and Management 1, pp. 414-426.

Ahuja, G., and Lampert, C. M. (2001). Entrepreneurship in the large corporation: A longitudinal study of how established firms create breakthrough inventions. Strategic Management Journal 22, pp. 521-543.

Alan, Y., Gao, G.P., and Gaur, V. (2014). Does Inventory Productivity Predict Future Stock Returns? A Retailing Industry Perspective. Management Science, pp. 2416-2434.

Berger, A.N., and Hannan, T.H. (1998). The efficiency cost of market power in the banking industry: A test of the "quiet life" and related hypotheses. Review of Economics and Statistics 80, pp. 454-465.

Bharadwaj, S., Bharadwaj, A., and Bendoly, E. (2007). The performance effects of complementarities between information systems, marketing, manufacturing, and supply chain processes. Information Systems Research 18, pp. 437453.

Bourgeois, L.J. (1981). On the measurement of organizational slack. Academy of Management Review 6, pp. 29-39.

Cachon, G.P., and Fisher, M. (2000). Supply chain inventory management and the value of shared information. Management Science 46, pp. 1032-1048.

Cachon, G.P., and Olivares, M. (2010). Drivers of finished-goods inventory in the US automobile industry. Management Science 56, pp. 202-216.

Capkun, V., Hameri, A.-P., and Weiss, L.A. (2009). On the relationship between inventory and financial performance in manufacturing companies. International Journal of Operations \& Production Management 29, pp. 789-806.

Chan, L.M., Shen, Z.M., Simchi-Levi, D., and Swann, J.L. (2004). Coordination of pricing and inventory decisions: a survey and classification, Handbook of Quantitative Supply Chain Analysis. Springer, pp. 335-392.
Chen, H., Frank, M.Z., and Wu, O.Q. (2005). What actually happened to the inventories of American companies between 1981 and 2000? Management Science 51, pp. 1015-1031.

Chen, H., Frank, M.Z., and Wu, O.Q. (2007). US retail and wholesale inventory performance from 1981 to 2004. Manufacturing \& Service Operations Management 9, pp. 430-456.

Cooper, R., and Maskell, B. (2008). How to manage through worsebefore-better. MIT Sloan Management Review 49, pp. 58-65.

Culpan, T. (2013). TSMC Climbs After Saying Inventories Will Decline: Taipei Mover, Bloomberg

De Menezes, L.M., Wood, S., and Gelade, G. (2010). The integration of human resource and operation management practices and its link with performance: a longitudinal latent class study. Journal of Operations Management 28, pp. 455471 .

Demeter, K., and Matyusz, Z. (2011). The impact of lean practices on inventory turnover. International Journal of Production Economics 133, pp. 154-163.

Downs, B., Metters, R., and Semple, J. (2001). Managing inventory with multiple products, lags in delivery, resource constraints, and lost sales: A mathematical programming approach. Management Science 47, pp. 464-479.

Dutta, S., Narasimhan, O., and Rajiv, S. (1999). Success in hightechnology markets: Is marketing capability critical? Marketing Science 18, pp. 547-568.

Ericson, R., and Pakes, A. (1995). Markov-perfect industry dynamics: A framework for empirical work. The Review of Economic Studies 62, pp. 53-82.

Eroglu, C., and Hofer, C. (2011). Lean, leaner, too lean? The inventory-performance link revisited. Journal of Operations Management 29, pp. 356-369.

Eroglu, C., and Hofer, C. (2014). The effect of environmental dynamism on returns to inventory leanness. Journal of Operations Management 32, pp. 347-356.

Evans, R.V. (1968). Sales and restocking policies in a single item inventory system. Management Science 14, pp. 463-472.

Fawcett, S. E., Magnan, G. M., and McCarter, M. W. (2008). Benefits, barriers, and bridges to effective supply chain management. Supply Chain Management: An International Journal 13(1), pp. 35-48.

Galbraith, J.R. (1973). Designing complex organizations. AddisonWesley Longman Publishing Co.Inc. , New York

Gaur, V., Fisher, M.L., and Raman, A. (2005). An econometric analysis of inventory turnover performance in retail services. Management Science 51, pp. 181-194.

Gaur, V., and Kesavan, S. (2009). The effects of firm size and sales growth rate on inventory turnover performance in the U.S retail sector, Retail Supply Chain Management. Springer, pp. 25-52.

Gaur, V., and Seshadri, S. (2005). Hedging inventory risk through market instruments. Manufacturing \& Service Operations Management 7, pp. 103-120.

Hall, B. (2012). Wal-Mart Seeks \$5 Billion U.S. Sales Gain from Fuller Inventory Levels, Bloomberg March 8, 2012 (accessed 20, August 2016)

Hall, R.W. (1983). Zero inventories. Dow Jones-Irwin, Homewood, IL

Hendricks, K.B., and Singhal, V.R. (2005). An Empirical Analysis of the Effect of Supply Chain Disruptions on Long Run Stock Price Performance and Equity Risk of the Firm. Production and Operations Management 14, pp. 35-52.

Hendricks, K.B., Singhal, and V.R., Zhang, R. (2009). The effect of operational slack, diversification, and vertical relatedness on the stock market reaction to supply chain disruptions. Journal of Operations Management 27, pp. 233-246.

Herzberg, F. (1974). Motivation-hygiene profiles: Pinpointing what ails the organization. Organizational Dynamics 3, pp. 18-29. 
Hines, P., Holweg, M., and Rich, N. (2004). Learning to evolve: a review of contemporary lean thinking. International Journal of Operations \& Production Management 24, pp. 994-1011.

Holt, C. C. (2004). Forecasting Trends and Seasonal by Exponentially Weighted Averages. International Journal of Forecasting 20(1), pp. 5-10.

Hofer, C., Eroglu, C., and Rossiter Hofer, A. (2012). The effect of lean production on financial performance: The mediating role of inventory leanness. International Journal of Production Economics 138, pp. 242-253.

Hooley, G.J., Greenley, G.E., Cadogan, J.W., and Fahy, J. (2005). The performance impact of marketing resources. Journal of Business Research 58, pp. 18-27.

Huson, M., and Nanda, D. (1995). The impact of just-in-time manufacturing on firm performance in the US. Journal of Operations Management 12, pp. 297-310.

Inman, R.A., Sale, R.S., Green Jr, K.W., and Whitten, D. (2011). Agile manufacturing: relation to JIT, operational performance and firm performance. Journal of Operations Management 29, pp. 343-355.

Irvine, F.O. (1981). Retail inventory investment and the cost of capital. The American Economic Review 71, pp. 633-648.

Jovanovic, B. (1982). Selection and the Evolution of Industry. Econometrica: Journal of the Econometric Society 50, pp. 649-670.

Kaskey, J. (2014). Caterpillar Raises Forecast on Construction Outlook, Bloomberg, available at https://www.bloomberg.com/news/articles/2014-0424/caterpillar-raises-2014-forecast-profit-beats-estimates (accessed 18, September 2016)

Kher, H.V., and Laurenceau, J.-P. (2011). Latent Growth Models for Operations Management Research: A Methodological Primer, In: Jaber, M.Y. (Ed), Learning Curves: Theory, Models, and Applications. CRC Pressure, Boca Raton, FL, pp. 237-264.

Kleindorfer, P.R., and Saad, G.H. (2005). Managing disruption risks in supply chains. Production and Operations Management 14, pp. 53-68.

Kolias, G.D., Dimelis, S.P., and Filios, V.P. (2011). An empirical analysis of inventory turnover behaviour in Greek retail sector: 2000-2005. International Journal of Production Economics 133, pp. 143-153.

Langley, A. (1999). Strategies for theorizing from process data. Academy of Management review 24, pp. 691-710.

Lawrence, P.R., and Lorsch, J.W. (1967). Differentiation and integration in complex organizations. Administrative Science Quarterly 12, pp. 1-47.

Lee, H.L. (2004). The triple-A supply chain. Harvard Business Review 82, pp. 102-113.

Lee, H.L., Billington, C. (1992). Managing supply chain inventory: pitfalls and opportunities. Sloan Management Review 33(3), pp. 65-73.

Lee, H.L., Padmanabhan, V., and Whang, S. (2004). Information distortion in a supply chain: the bullwhip effect. Management Science 50, pp. 1875-1886.
Modi, S.B., and Mishra, S. (2011). What drives financial performance---resource efficiency or resource slack?: Evidence from US Based Manufacturing Firms from 1991 to 2006. Journal of Operations Management 29, pp. 254-273.

Morgan, N.A., Kaleka, A., and Gooner, R.A. (2007). Focal supplier opportunism in supermarket retailer category management. Journal of Operations Management 25, pp. 512-527.

Politis, D. (2005). The process of entrepreneurial learning: a conceptual framework. Entrepreneurship Theory and Practice 29, pp. 399-424.

Qin, Y., Wang, R., Vakharia, A.J., Chen, Y., and Seref, M.M. (2011). The newsvendor problem: Review and directions for future research. European Journal of Operational Research 213, pp. 361-374.

Rabinovich, E., Dresner, M.E., and Evers, P.T. (2003). Assessing the effects of operational processes and information systems on inventory performance. Journal of Operations Management 21, pp. 63-80.

Rajagopalan, S. (2013). Impact of variety and distribution system characteristics on inventory levels at US retailers. Manufacturing \& Service Operations Management 15, pp. 191-204.

Rajagopalan, S., and Malhotra, A. (2001). Have US manufacturing inventories really decreased? An empirical study. Manufacturing \& Service Operations Management 3, pp. 1424.

Rumyantsev, S., and Netessine, S. (2007). What can be learned from classical inventory models? A cross-industry exploratory investigation. Manufacturing \& Service Operations Management 9, pp. 409-429.

Schmenner, R.W. (2001). Looking ahead by looking back: swift, even flow in the history of manufacturing. Production and Operations Management 10, pp. 87-96.

Schonberger, R.J. (2007). Japanese production management: An evolution-With mixed success. Journal of Operations Management 25, pp. 403-419.

Shan, J., and Zhu, K. (2013). Inventory management in China: An empirical study. Production and Operations Management 22, pp. 302-313

Steinker, S., and Hoberg, K. (2013). The impact of inventory dynamics on long-term stock returns-An empirical investigation of US manufacturing companies. Journal of Operations Management 31, pp. 250-261.

Timberlake, C. (2011). Saks CEO Sadove Tightens Inventory So Recession Wasn't Wasted, Bloomberg August 29, 2011 (accessed 10, July 2016).

Urban, T.L. (2005). Inventory models with inventory-leveldependent demand: A comprehensive review and unifying theory. European Journal of Operational Research 162, pp. 792-804.

Wooldridge, J.M. (2010). Econometric analysis of cross section and panel data. MIT press, Cambridge, MA

Pankaj Patel is an Associate Professor at Villanova University.

Andrew Manikas is an Assistant Professor at the University of Louisville, College of Business, Management Department.

Before academia he worked as a management consultant for Deloitte and Touche, as well as KPMG Peat Marwick. 